\title{
DECISION SUPPORT SYSTEM FOR DETERMINING BEST HOMEROOM TEACHER WITH TOPSIS METHOD IN MIS NURUL HUDA PANTAI LABU
}

\author{
Elisa Purba ${ }^{1}$, Desi Vinsensia ${ }^{2}$, Yulia Utami ${ }^{3}$ \\ 1,23STMIK Pelita Nusantara Medan \\ 1,2 3Jurusan Teknik Informatika \\ e-mail: *1elisapurba@gmail.com,2desivinsensia87@gmail.com, \\ 3yulia_utami@rocketmail.com
}

\begin{abstract}
During this time the determination of the best homeroom teacher at MIS Nurul Huda Pantai Labu was still using a manual process, so the results were not optimal. In this study the decision support system was built to facilitate the school in determining the best homeroom teacher using the Topsis method. The criteria used are 5: attendance, organizational experience, data on student achievement, interaction with students, and final education. This system design application is expected to help the school principal in making decisions about determining the best homeroom teacher
\end{abstract}

Keywords : homeroom teacher, MIS Nurul Huda School, Topsis Method

Abstrak. Selama ini penentuan wali kelas terbaik yang dilakukan di sekolah MIS Nurul Huda Pantai Labu masih menggunakan proses manual sehingga hasilnya kurang maksimal. Dalam penelitian ini dibangun sistem pendukung keputusan yang memudahkan pihak sekolah dalam penentuan wali kelas terbaik dengan menggunakan metode Topsis. Kriteria yang digunakan ada 5 yaitu: absensi, pengalaman organisasi, data prestasi siswa, interaksi terhadap siswa, dan pendidikan terakhir. Aplikasi perancangan sistem ini diharapkan dapat membantu kepala sekolah dalam pengambilan keputusan penentuan wali kelas terbaik

Kata kunci. wali kelas, MIS Nurul Huda, Metode Topsis. 


\section{PENDAHULUAN}

Guru merupakan salah satu komponen komponen penting dalam penyelenggaraan proses belajar mengajar (PBM) di sekolah. Dalam Peratuturan Pemerintah (Perpu) Republik Indonesia Nomor 19 tahun 2017 guru adalah pendidik professional dengan tugas utama mendidik, mengajar, membimbing, mengarahkan, melatih, menilai, dan mengevaluasi peserta didik pada pendidikan anak usia dini jalur pendidikan formal, pendidikan dasar, dan pendidikan menengah

Evaluasi kinerja SDM yakni guru perlu dilakukan untuk meningkatkan kualitas layanan tugas terhadap peserta didik.Hal ini dilakukan oleh kepala sekolah selaku pemimpin sebagai pengukuran prestasi kinerja guru dan wali kelas dalam mendidik, mengajar serta membimbing peserta didiknya.Untuk itu sistem pengambilan keputusan perlu dibuat suatu teknologi komputerisasi sebagai alat bantu pengambilan keputusan manajerial yang memiliki beragam konteks yang berbeda. MIS (Madrasah Ibtidaiyah Swasta) Nurul Huda beralamat di Jalan Persatuan No. 235 Dusun II, Desa Denai Sarang Burung, Kecamatan Pantai Labu, Kabupaten Deli Serdang ini, memiliki enam orang guru masing-masing menjabat sebagai wali kelas. MIS Nurul Huda merupakan madrasah yang belum menjadi madrasah favorit.Oleh karena itu, guna meningkatkan kredibilitas sekolah sekaligus memotivasi para guru dalam meninngkatkan prestasinya maka salah satu caranya adalah penentuan wali kelas terbaik.

Dalam sekolah MIS Nurul Huda dalammelakukan pemilihan wali kelas terbaikmasih secara manual, hal ini memungkinkan terpilihnya wali kelas tidak mencapai standart yang diinginkan dan tidak memperoleh kandidat yang baik. Sistem ini bertujuan untuk memudahkan dalam mengelola data yang ada pada Madrasah tersebut secara mudah, cepat dan akurat. Untuk memberikan kemudahan dalam penetuan calon Wali Kelas terbaik, maka dibutuhkan sistem yang dapat memfasilitasi proses secara sistematis dan sesuai prosedurBagaimana Membangun "Sistem Pendukung Keputusan Penentuan Wali Kelas Terbaik Dengan Metode Topsis" sebagai metode pengambilan keputusan yang dapat membantu pihak sekolah dalam menentukan kebijakan terkait dengan metode topsis.

Pada penelitian tentang aplikasi pendukung keputusan pemilihan smartphone menyimpulkan bahwa metode TOPSIS dapat digunakan untuk memberikan penilaian smartphonedalam aplikasi sistem pendukung keputusan pemilihan smartphone.[1] Selanjutnyadalam penelitian tentang sistem pendukung keputusan penilaian kinerja karyawan menggunakan metode TOPSIS berbasis web dan disimpulkan bahwa perusahaan dapat mendapat kinerja karyawan yang lebih professional dari hasil perhitungan pada aplikasi sistem pendukung keputusan yang dibuat [4]. Pada penelitian sebelumnyatentang sistem pendukung keputusan pemilihan guru teladan di SMA Era UtamaPancur Batu menggunakan metode 
TOPSIS menggunakan 6 kriteria, yaitu : Nilai Bahasa Asing, absensi, penilaian sejawat, penilaian siswa, kwalitas mengajar, nilai Psikotest.[6]

\section{METODE PENELITIAN}

1. Algoritma Sistem

Algoritma metode Topsis adalah sebuah metode perencanaan strategis yang digunakan dalam merancang sistem informasi dengan menggunakan pendekatan dari algoritma-algoritma yang sederhana guna memberi solusi ideal yang dibutuhkan bagi user. Analisis algoritma tersebut akan dirancang untuk mengevaluasi apa yang dibutuhkan dalam membangun proyek dan informasi apa yang akan dihasilkan oleh sistem informasi tersebut.

2. Menentukan Data Kriteria

Dalam metode Topsis ini memerlukan bobot dan kriteria yang dibutuhkan untuk menentukan penentuan wali kelas terbaik. Adapun kriteria yang telah ditentukan adalah sebagai berikut :

a. Absensi wali kelas

b. Pengalaman Organisasi

c. Data Prestasi Siswa

d. Interaksi terhadap siswa

e. Pendidikan Terakhir

Tabel 2.1 Kriteria Penentuan Wali Kelas Terbaik

\begin{tabular}{|c|c|c|c|}
\hline No & Kriteria \& Sub Kriteria & Nilai & Keterangan \\
\hline 1. & $\begin{array}{l}\text { Absensi wali kelas } \\
\text { - } 1 \text { Semester }=1-6 \text { hari tidak hadir } \\
\text { - } 1 \text { Semester }=7-12 \text { hari tidak hadir } \\
\text { - } 1 \text { Semester }=13-16 \text { hari tidak hadir } \\
\text { - } 1 \text { Semester }=17-20 \text { hari tidak hadir }\end{array}$ & $\begin{array}{l}5 \\
4 \\
3 \\
2\end{array}$ & $\begin{array}{c}\text { Sangat Baik } \\
\text { Baik } \\
\text { Cukup Baik } \\
\text { Kurang Baik }\end{array}$ \\
\hline 2. & $\begin{array}{l}\text { Pengalaman Organisasi } \\
\text { - } 1-2 \text { Bulan } \\
\text { - } 3-6 \text { Bulan } \\
\text { - } 7-9 \text { Bulan } \\
\text { - } 10-12 \text { Bulan } \\
\end{array}$ & $\begin{array}{l}2 \\
3 \\
4 \\
5\end{array}$ & $\begin{array}{c}\text { Kurang Baik } \\
\text { Cukup Baik } \\
\text { Baik } \\
\text { Sangat Baik }\end{array}$ \\
\hline 3. & $\begin{array}{l}\text { Data Prestasi Siswa } \\
\text { - } 65-75 \\
\text { - } 76-80 \\
\text { - } 81-85 \\
\text { - } 86-90\end{array}$ & $\begin{array}{l}2 \\
3 \\
4 \\
5\end{array}$ & $\begin{array}{c}\text { Kurang Baik } \\
\text { Cukup Baik } \\
\text { Baik } \\
\text { Sangat Baik }\end{array}$ \\
\hline
\end{tabular}




\begin{tabular}{|c|c|c|c|}
\hline 4. & $\begin{array}{l}\text { Interaksi terhadap siswa } \\
\text { - 1. Mengenal nama-nama siswa (1- 4) } \\
\text { - 2. Memahami karakteristik siwa (1- } \\
\text { 3) } \\
\text { - 3. Banyak berbicara pada siswa (1- } \\
\text { 2) } \\
\text { - 4. Perduli terhadap siswa (1) }\end{array}$ & $\begin{array}{l}5 \\
4 \\
3 \\
2\end{array}$ & $\begin{array}{c}\text { Sangat Baik } \\
\text { Baik } \\
\text { Cukup Baik } \\
\text { Kurang Baik }\end{array}$ \\
\hline 5. & $\begin{array}{l}\text { Pendidikan Terakhir } \\
\text { - } 1 . \text { SMA/SLTA } \\
\text { - } 2 . \text { S-1 (S.Pd.) } \\
\text { - } 3 . \text { S-2 (M.Pd.) }\end{array}$ & $\begin{array}{l}3 \\
4 \\
5\end{array}$ & $\begin{array}{c}\text { Cukup } \\
\text { Baik } \\
\text { Sangat Baik }\end{array}$ \\
\hline
\end{tabular}

Dari kriteria tersebut, maka dibuat suatu tingkat kepentingan kriteria berdasarkan nilai bobot. Rating kecocokan setiap alternatif pada setiap kriteria diantaranya yaitu sebagai berikut :
- Sangat Baik (A)
$=5$
- $\operatorname{Baik}($ B )
$=4$
- Cukup Baik ( C )
$=3$
- Kurang Baik (D)
$=2$

Dibawah ini akan ditampilkan tabel pembererian bobot untuk alternatif yang telah ditentukan :

Tabel 2.2 Bobot Kriteria Yang Ditentukan

\begin{tabular}{|c|c|c|c|}
\hline NO & Kriteria Penilaian \& Sub Kriteria & Simbol & Nilai Bobot \\
\hline 1. & $\begin{array}{l}\text { Absensi wali kelas } \\
\text { - } 1 \text { Semester }=1-6 \text { hari tidak hadir } \\
\text { - } 1 \text { Semester }=7-12 \text { hari tidak hadir } \\
\text { - } 1 \text { Semester }=13-16 \text { hari tidak hadir } \\
\text { - } 1 \text { Semester }=17-20 \text { hari tidak hadir }\end{array}$ & K 1 & $\begin{array}{l}5 \\
4 \\
3 \\
2\end{array}$ \\
\hline 2. & $\begin{array}{l}\text { Pengalaman Organisasi } \\
\text { - } 1-3 \text { Bulan } \\
\text { - } 4-6 \text { Bulan } \\
\text { - } 7-9 \text { Bulan } \\
\text { - } 10-12 \text { Bulan }\end{array}$ & K 2 & $\begin{array}{l}5 \\
4 \\
3 \\
2\end{array}$ \\
\hline
\end{tabular}




\begin{tabular}{|c|c|c|c|}
\hline 3. & $\begin{array}{l}\text { Data Prestasi Siswa } \\
\text { - } 65-75 \\
\text { - } 76-80 \\
\text { - } 81-85 \\
\text { - } 86-90\end{array}$ & K 3 & $\begin{array}{l}5 \\
4 \\
3 \\
2\end{array}$ \\
\hline 4. & $\begin{array}{l}\text { Interaksi terhadap siswa } \\
\text { - } 1 . \text { Mengenal nama-nama siswa (1-4) } \\
\text { - 2. Memahami karakteristik siswa (1-3) } \\
\text { - 3. Banyak berbicara pada siswa (1-2) } \\
\text { - 4. Perduli terhadap siswa (1) }\end{array}$ & K4 & $\begin{array}{l}5 \\
4 \\
3 \\
2\end{array}$ \\
\hline 5. & $\begin{array}{l}\text { Pendidikan Terakhir } \\
\text { - SMA/SLTA } \\
\text { - S-1 (S.Pd.) } \\
\text { - S-2 (M.Pd.) }\end{array}$ & K 5 & $\begin{array}{l}5 \\
4 \\
3 \\
2\end{array}$ \\
\hline
\end{tabular}

3. Menentukan Rating Alternatif Pada Setiap Kriteria

Berikutini ditampilkan tabel data penentuan wali kelas terbaik dari 5 (lima) kriteria yang akan dihitung dengan metode Topsis :

Tabel 3.3 Data Penentuan Wali Kelas Terbaik

\begin{tabular}{|c|c|c|c|c|c|c|c|}
\hline \multirow[b]{2}{*}{ Kriteria } & \multirow[b]{2}{*}{$\begin{array}{l}\mathrm{Si} \\
\mathrm{m} \\
\mathrm{bo} \\
\mathrm{l}\end{array}$} & \multicolumn{6}{|c|}{ Data Penentuan Wali Kelas Terbaik } \\
\hline & & $\begin{array}{c}\text { Kelas } 1 \\
\text { Nurul } \\
\text { Khadijah }\end{array}$ & $\begin{array}{c}\text { Kelas II } \\
\text { Hamidah }\end{array}$ & $\begin{array}{c}\text { Kelas III } \\
\text { Sri Susanti }\end{array}$ & $\begin{array}{c}\text { Kelas IV } \\
\text { Novita } \\
\text { Sari S.Pd }\end{array}$ & $\begin{array}{l}\text { Kelas V } \\
\text { M. Ali }\end{array}$ & $\begin{array}{l}\text { Kelas VI } \\
\text { Siti } \\
\text { Ardiyant } \\
\text { i M.Th }\end{array}$ \\
\hline $\begin{array}{c}\text { Absensi } \\
\text { wali kelas }\end{array}$ & $\begin{array}{l}K \\
1\end{array}$ & $\begin{array}{c}1 \\
\text { Semester } \\
15 \text { hari } \\
\text { tidak } \\
\text { hadir }\end{array}$ & $\begin{array}{c}1 \\
\text { Semester } \\
18 \text { hari } \\
\text { tidak } \\
\text { hadir }\end{array}$ & $\begin{array}{c}1 \\
\text { Semester } 8 \\
\text { hari tidak } \\
\text { hadir }\end{array}$ & $\begin{array}{c}1 \\
\text { Semeste } \\
\text { r } 6 \text { hari } \\
\text { tidak } \\
\text { hadir }\end{array}$ & $\begin{array}{c}1 \\
\text { Semest } \\
\text { er } 12 \\
\text { hari } \\
\text { tidak } \\
\text { hadir }\end{array}$ & $\begin{array}{c}1 \\
\text { Semeste } \\
r \\
5 \text { hari } \\
\text { tidak } \\
\text { hadir }\end{array}$ \\
\hline $\begin{array}{l}\text { Pengalam } \\
\text { an } \\
\text { Organisas } \\
\text { i }\end{array}$ & $\begin{array}{l}K \\
2\end{array}$ & 12 Bulan & $\begin{array}{c}3 \\
\text { Bulan }\end{array}$ & $\begin{array}{c}2 \\
\text { Bulan }\end{array}$ & $\begin{array}{c}3 \\
\text { Bulan }\end{array}$ & $\begin{array}{c}24 \\
\text { Bulan }\end{array}$ & $\begin{array}{c}6 \\
\text { Bulan }\end{array}$ \\
\hline
\end{tabular}




\begin{tabular}{|c|c|c|c|c|c|c|c|}
\hline $\begin{array}{c}\text { Data } \\
\text { Prestasi } \\
\text { Siswa }\end{array}$ & $\begin{array}{l}\mathrm{K} \\
3\end{array}$ & $65-75$ & $76-80$ & $76-80$ & $81-85$ & $86-90$ & $86-90$ \\
\hline $\begin{array}{c}\text { Interaksi } \\
\text { terhadap } \\
\text { siswa }\end{array}$ & $\begin{array}{l}K \\
4\end{array}$ & $\begin{array}{l}1 . \\
\text { Banyak } \\
\text { berbicara } \\
\text { pada } \\
\text { siswa. } \\
2 . \\
\text { Perduli } \\
\text { terhadap } \\
\text { siswa }\end{array}$ & $\begin{array}{l}1 . \\
\text { Perduli } \\
\text { Terhadap } \\
\text { siswa }\end{array}$ & $\begin{array}{l}1 . \\
\text { Memahami } \\
\text { karakteristi } \\
\text { k siswa } \\
2 . \\
\text { Banyak } \\
\text { berbicara } \\
\text { pada siswa } \\
\text { 3. } \\
\text { Perduli } \\
\text { Terhadap } \\
\text { Siswa }\end{array}$ & $\begin{array}{l}1 . \\
\text { Mengen } \\
\text { al nama- } \\
\text { nama } \\
\text { siswa } \\
2 . \\
\text { Memaha } \\
\text { mi } \\
\text { karakter } \\
\text { i } \\
\text { stik } \\
\text { siswa } \\
3 . \\
\text { Banyak } \\
\text { berbicar } \\
\text { a } \\
\text { pada } \\
\text { siswa } \\
4 . \\
\text { Perduli } \\
\text { terhada } \\
\text { p } \\
\text { siswa }\end{array}$ & $\begin{array}{l}1 . \\
\text { Memah } \\
\text { a } \\
\text { mi } \\
\text { karakt } \\
\text { eri } \\
\text { stik } \\
\text { siswa } \\
2 . \\
\text { Banyak } \\
\text { berbica } \\
\text { ra } \\
\text { pada } \\
\text { siswa }\end{array}$ & $\begin{array}{l}1 . \\
\text { Mengen } \\
\text { al } \\
\text { nama- } \\
\text { nama } \\
\text { siswa } \\
2 . \\
\text { Memaha } \\
\text { mi } \\
\text { karakter } \\
\text { is } \\
\text { tik siswa } \\
\text { 3. } \\
\text { Banyak } \\
\text { berbicar } \\
\text { a } \\
\text { pada } \\
\text { siswa } \\
4 . \\
\text { Perduli } \\
\text { terhada } \\
\text { p } \\
\text { siswa }\end{array}$ \\
\hline $\begin{array}{c}\text { Pendidika } \\
\text { n } \\
\text { Terakhir }\end{array}$ & $\begin{array}{l}\mathrm{K} \\
5\end{array}$ & $\begin{array}{l}\text { SMA/ } \\
\text { SLTA }\end{array}$ & $\begin{array}{l}\text { SMA/ } \\
\text { SLTA }\end{array}$ & $\begin{array}{l}\text { SMA/ } \\
\text { SLTA }\end{array}$ & $\begin{array}{c}S-1 \\
(S . P d)\end{array}$ & $\begin{array}{c}\text { SMA/S } \\
\text { LTA }\end{array}$ & $\begin{array}{c}\text { S-2 } \\
\text { (M.Th) }\end{array}$ \\
\hline
\end{tabular}


Berdasarkan data diatas dapat dibentuk rating kecocokan dari setiap alternatif pada kriteria yang telah dikonversikan seperti pada tabel dibawah ini :

Tabel 2.4 Rating Kecocokan Dari Setiap Alternatif Pada Setiap Kriteria

\begin{tabular}{|c|c|c|c|c|c|c|}
\hline \multirow{2}{*}{ Alternatif } & \multirow{5}{*}{ Nama Wali Kelas } & \multicolumn{5}{|c|}{ Kriteria } \\
\cline { 3 - 7 } & & K1 & K2 & K3 & K4 & K5 \\
\hline A1 & Nurul Khadijah & 3 & 5 & 2 & 3 & 3 \\
\hline A2 & Hamidah & 2 & 3 & 3 & 2 & 3 \\
\hline A3 & Sri Susanti & 4 & 2 & 3 & 4 & 3 \\
\hline A4 & Novita Sari S.Pd & 5 & 3 & 4 & 5 & 4 \\
\hline A5 & M. Ali & 4 & 5 & 5 & 4 & 3 \\
\hline
\end{tabular}

Dari tabel diatas dapat diimplementasikan kedalam perhitungan Topsis sebagai berikut :

1. $\mathrm{Ai}=$ Alternatif penentuan wali kelas.

2. $\mathrm{Cj}=$ Kriteria yang menjadi acuan dalam penentuan wali kelas terbaik.

3. Bobot preferensi untuk kriteria $\left(C_{1}, C_{2}, C_{3}, C_{4}, C_{5}\right)$ adalah : $(5,4,3,2,5)$.

4. Berdasarkan tabel rating kecocokan, dapat dibtuk matriks keputusan $\mathrm{X}$.

4. Pembentukan Matriks Keputusan

Berdasarkan tabel rating kecocokan, dapat dibentuk matriks keputusan X. Yang menunjukkan ranking kecocokan dari setiap alternatif pada setiap kriteria adalah sebagai berikut :

Tabel 2.5 Matriks Keputusan X

\begin{tabular}{|c|c|c|c|c|c|}
\hline Alternatif & $\mathrm{K} 1$ & $\mathrm{~K} 2$ & $\mathrm{~K} 3$ & $\mathrm{~K} 4$ & $\mathrm{~K} 5$ \\
\hline $\mathrm{A} 1$ & 3 & 5 & 2 & 3 & 3 \\
\hline $\mathrm{A} 2$ & 2 & 3 & 3 & 2 & 3 \\
\hline A3 & 4 & 2 & 3 & 4 & 3 \\
\hline
\end{tabular}




\begin{tabular}{|c|c|c|c|c|c|}
\hline A4 & 5 & 3 & 4 & 5 & 4 \\
\hline A5 & 4 & 5 & 5 & 4 & 3 \\
\hline A6 & 5 & 3 & 5 & 5 & 5 \\
\hline
\end{tabular}

Kriteria-kriteria dan matrix keputusan sudah dilakukan seperti yang ada pada tabel rating kecocokan.

Pertama (1) membuat matriks keputusan $\mathrm{X}$ ternormalisasi untuk menghitung nilai masing-masing kriteria dengan persamaan

$\boldsymbol{r}_{i j}=\frac{\boldsymbol{x}_{i j}}{\sqrt{\sum_{i=1}^{m} x_{i j}^{2}}} ;$ dengan $\mathrm{i}=1,2 . ., \mathrm{m}$ dan $\mathrm{j}=1,2, \ldots ., \mathrm{n}$

5. Normalisasi Matriks R

Membuat normalisasi matriks $\mathrm{R}$ yang diperoleh dari hasil normalisasi matriks X sebagai berikut :

Tabel 2.6 Normalisasi Matriks R

\begin{tabular}{|c|c|c|c|c|c|}
\hline Alternatif & K1 & K2 & K3 & K4 & K5 \\
\hline A1 & 0,3077 & 0,5555 & 0,2132 & 0,3077 & 0,3418 \\
\hline A2 & 0,2051 & 0,3333 & 0,3198 & 0,2051 & 0,3418 \\
\hline A3 & 0,4103 & 0,2222 & 0,3198 & 0,4103 & 0,3418 \\
\hline A4 & 0,5129 & 0,3333 & 0,4264 & 0,5129 & 0,4558 \\
\hline A5 & 0,4103 & 0,5555 & 0,5330 & 0,4103 & 0,3418 \\
\hline A6 & 0,5129 & 0,3333 & 0,5330 & 0,5129 & 0,5698 \\
\hline
\end{tabular}

Kedua (2) menentukan matriks yang ternormalisasi terbobot dengan mengkalikan bobot $(\mathrm{w})$ dengan rating kinerja $\left(r_{i j}\right)$ berdasarkan persamaan $y_{i j}=$ $w_{i} * r_{i j}$ yaitu didapatkan dari perkalian matriks $\mathrm{R}$ dengan bobot preferensi $\mathrm{W}$ $\left[5,4,3,2,5\right.$. Sehingga diperoleh matriks Y dari perkalian $\mathrm{w}^{*} r_{i j}$ sebagai berikut :

Tabel 2.7 Matriks Y

\begin{tabular}{|c|c|c|c|c|c|}
\hline Matriks & K1 & K2 & K3 & K4 & K5 \\
\hline \multirow{2}{*}{} & 1,5385 & 2,222 & 0,6396 & 0,6154 & 1,709 \\
\cline { 2 - 6 } & 1,0255 & 1,3332 & 0,9594 & 0,4102 & 1,709 \\
\hline
\end{tabular}




\begin{tabular}{|c|c|c|c|c|c|}
\hline \multirow{2}{*}{$\mathrm{Y}$} & 2,0515 & 0,8888 & 0,9594 & 0,8206 & 1,709 \\
\cline { 2 - 6 } & 2,5645 & 1,3332 & 1,2792 & 1,0258 & 2,279 \\
\cline { 2 - 6 } & 2,0515 & 2,222 & 1,599 & 0,8206 & 1,709 \\
\cline { 2 - 6 } & 2,5645 & 1,3332 & 1,599 & 1,0258 & 2,849 \\
\hline
\end{tabular}

Ketiga (3) menentukan solusi ideal positif dan solusi ideal negatif berdasarkan rating bobot yang ternormalisasi $y_{i j}$ dengan persamaan $A^{+}=\left(y_{1}{ }^{+}, y_{2}{ }^{+}, \ldots y_{n}{ }^{+}\right)$ dan $A^{-}=\left(y_{1}{ }^{-}, y_{2}{ }^{-}, \ldots y_{n}{ }^{-}\right)$

Keempat (4) menentukan jarak antara nilai alternatif dengan matriks solusi ideal positif dan solusi ideal negatif. Jarak antara nilai terbobot setiap alternatif terhadap solusi ideal positif $D_{i}^{+}=\sqrt{\sum_{j=i}^{n}\left(y_{i}^{-}-y_{i j}\right)^{2}}$

6. Perhitungan Dengan Metode Topsis

Kelima (5) menentukan nilai preferensi untuk setiap alternatif $\left(V_{i}\right)$, kedekatan setiap alternatif terhadap solusi ideal terhitung dengan persamaan $V_{i}=\frac{D_{i}^{-}}{D_{i}^{-}+D_{i}^{+}}$:

Tabel 2.8 Hasil Perhitungan Dengan Metode Topsis

\begin{tabular}{|c|l|c|c|c|c|c|c|c|}
\hline N0 & $\begin{array}{c}\text { Nama Wali } \\
\text { Kelas }\end{array}$ & K1 & K2 & K3 & K4 & K5 & Total & Keterangan \\
\hline 1. & Nurul Khadijah & 3 & 5 & 2 & 3 & 3 & 2,85 & \\
\hline 2. & Hamidah & 2 & 3 & 3 & 2 & 3 & 3,29 & \\
\hline 3. & Sri Susanti & 4 & 2 & 3 & 4 & 3 & 2,95 & \\
\hline 4. & Novita Sari S.Pd & 5 & 3 & 4 & 5 & 4 & 2,1 & \\
\hline 5. & M.Ali & 4 & 5 & 5 & 4 & 3 & 2,26 & \\
\hline 6. & $\begin{array}{l}\text { Siti Ardianti } \\
\text { M.Th }\end{array}$ & 5 & 3 & 5 & 5 & 5 & 1,89 & \\
\hline
\end{tabular}

Berdasarkan hasil perhitungan Metode Topsis diatas dari beberapa alternatif, dapat diperoleh hasil total yang tertinggi adalah pada nilai 3,29. Maka wali kelas terbaik adalah Ibu Hamidah guru kelas II di MIS Nurul Huda Pantai Labu.

7. Rancangan Flowchart Program

Sebelum pembuatan program terlebih dahulu dibuat suatu flowchart program.Flowchart merupakan bagan yang menunjukkan alur kerja atau apa yang 
sedang dikerjakan di dalam sistem secara keseluruhan dan menjelaskan urutan dari prosedur-prosedur yang ada di dalam sistem.

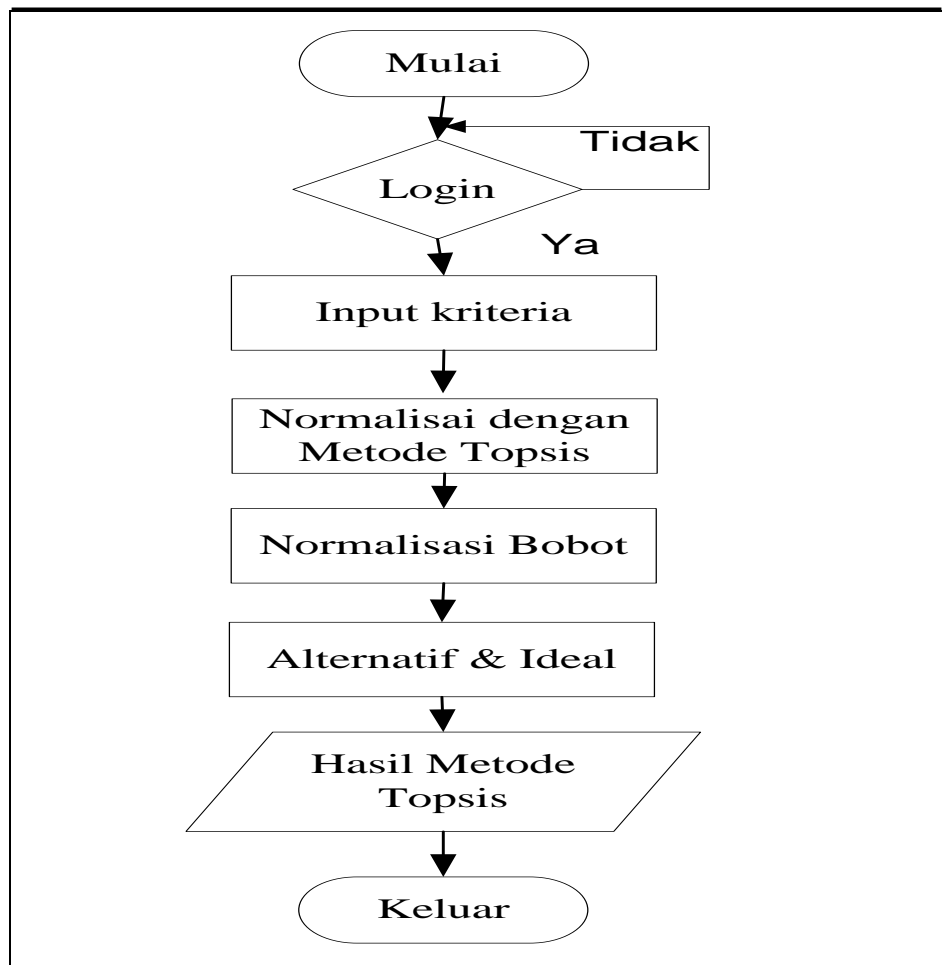

Gambar 2.1 FlowchartProgram Penentuan Wali Kelas

2. Use Case Diagram

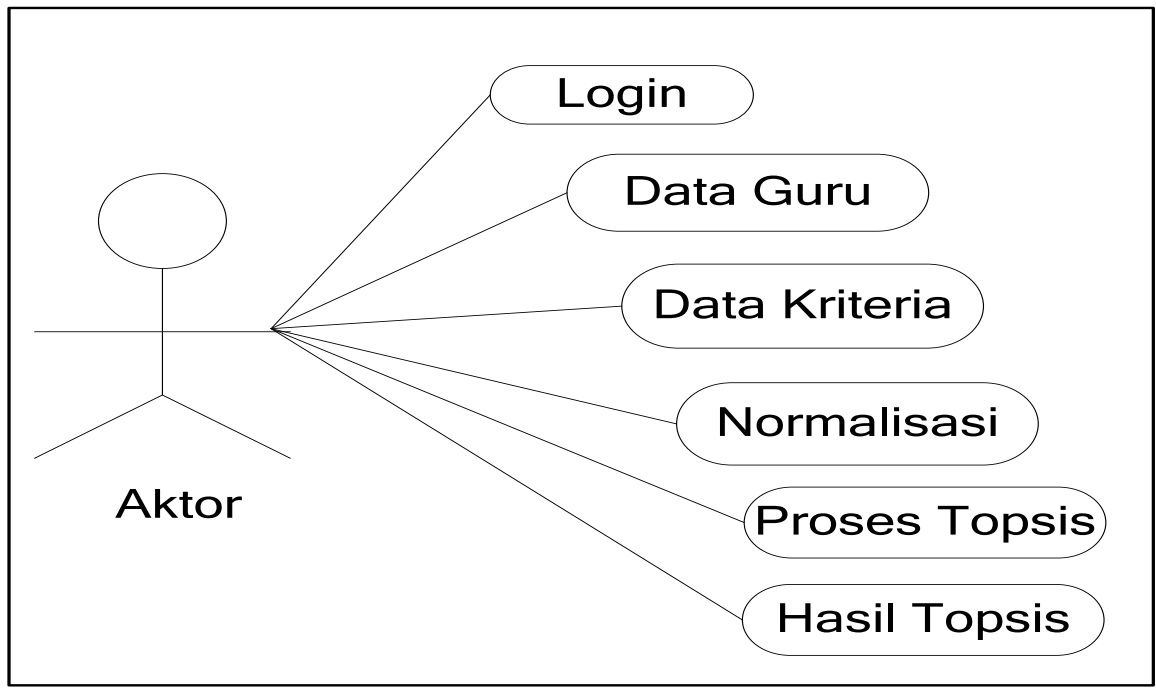

Gambar 2.2 PerancanganUse Case Diagram 
Tabel 2.9 Keterangan Use Case Diagram

\begin{tabular}{|c|c|}
\hline Nama & Deskripsi Use Case \\
\hline Aktor & Admin/pengguna. \\
\hline Stimulan & $\begin{array}{l}\text { Admin menggunakan sistem untuk pengambilan } \\
\text { keputusan penentuan wali kelas terbaik dengan metode } \\
\text { topsis. }\end{array}$ \\
\hline Kondisi awal & $\begin{array}{l}\text { Admin akan menggunakan aplikasi sistem pendukung } \\
\text { keputusan. }\end{array}$ \\
\hline Kondidi akhir & $\begin{array}{l}\text { Pengguna dapat melakukan proses pengambilan } \\
\text { keputusan penentuan wali kelas terbaik dengan metode } \\
\text { topsis. }\end{array}$ \\
\hline $\begin{array}{l}\text { Skenario } \\
\text { Use Case untuk } \\
\text { Login }\end{array}$ & $\begin{array}{ll}\text { Use Case } & \text { : Login } \\
\text { Aktor } & \text { : Administrator } \\
\text { Tujuan } & \quad \text { : Proses Validasi Admin } \\
\text { Deskripsi } & \text { : Administrator yang berkeinginan untuk } \\
& \text { masuk ke dalam administrator. Admin } \\
& \text { Login dengan memasukkan username } \\
& \text { dan password. }\end{array}$ \\
\hline $\begin{array}{l}\text { Skenario } \\
\text { Use Case untuk } \\
\text { Data Guru }\end{array}$ & $\begin{array}{ll}\text { Use Case } & \text { : Data Guru } \\
\text { Aktor } & \text { : Administrator } \\
\text { Tujuan } & \quad \text { : Menginput Data Guru } \\
\text { Deskripsi } & : \text { Administrator mengimput seluruh data } \\
& \begin{array}{l}\text { guru yang akan dilakukan penilaan } \\
\text { dalam menentukan walikelas terbaik. }\end{array}\end{array}$ \\
\hline $\begin{array}{l}\text { Skenario } \\
\text { Use Case untuk } \\
\text { Data Kriteria }\end{array}$ & $\begin{array}{ll}\text { Use Case } & \text { : Kriteria } \\
\text { Aktor } & \text { : Administrator } \\
\text { Tujuan } & \text { : Data Kriteria } \\
\text { Deskripsi } & \text { : Administrator mengimput data } \\
& \text { kriteria untuk dilakukan normalisasi } \\
& \text { untuk diproses dengan metode Topsis. }\end{array}$ \\
\hline $\begin{array}{l}\text { Skenario } \\
\text { Use Case untuk } \\
\text { Metode TOPSIS }\end{array}$ & $\begin{array}{ll}\text { Use Case } & \text { : Metode Topsis } \\
\text { Aktor } & \text { : Administrator } \\
\text { Tujuan } & \text { : Memproses data dengan Topsis } \\
\text { Deskripsi } & \text { : Administrator memasukkan data walikelas, } \\
& \text { dan melakukan proses perhitungan } \\
& \text { dengan nilai kriteria yang telah } \\
& \text { ditentuakan maka proses metode topsis } \\
& \text { dapat menghasilkan sebuah keputusan } \\
& \text { dalam menentukan wali kelas terbaik. }\end{array}$ \\
\hline
\end{tabular}




\section{HASIL DAN PEMBAHASAN}

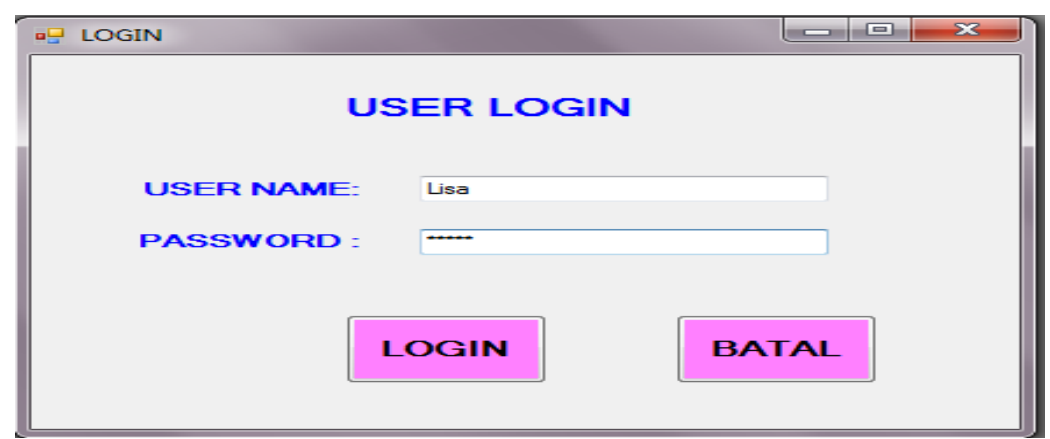

Gambar 3.1 Form Login

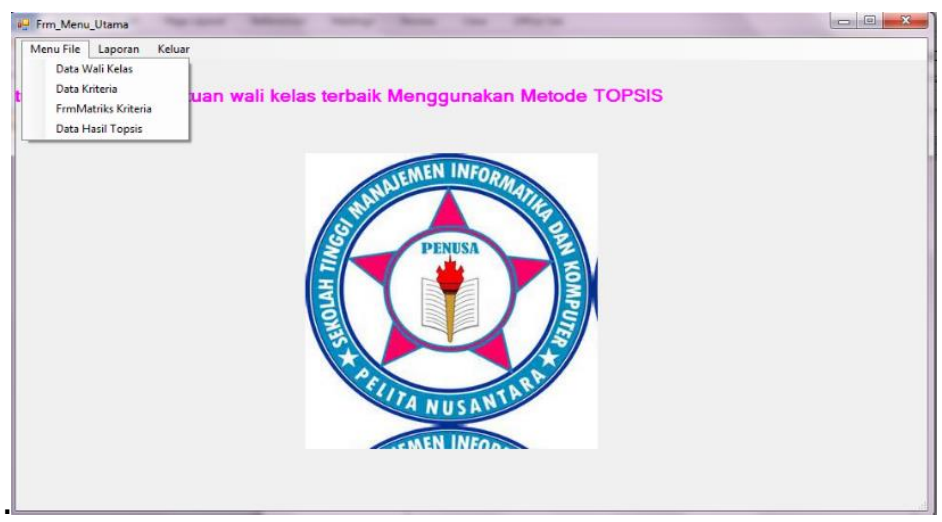

Gambar 3.2 Menu Utama (File)

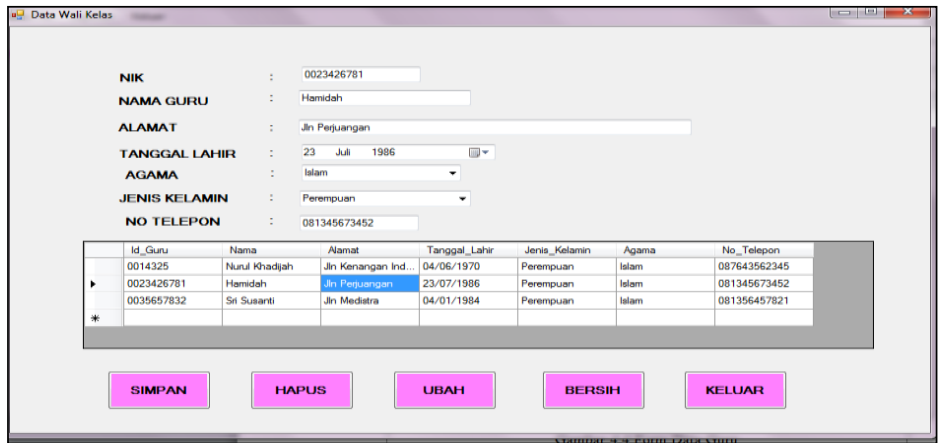

Gambar 3.3 Form Data Wali Kelas 


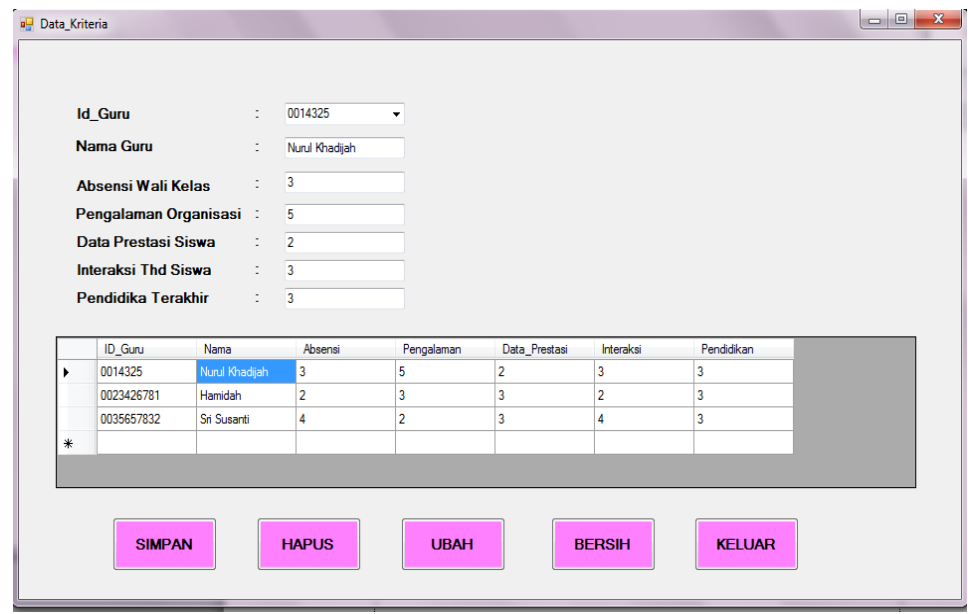

Gambar 3.4 Form Data Kriteria

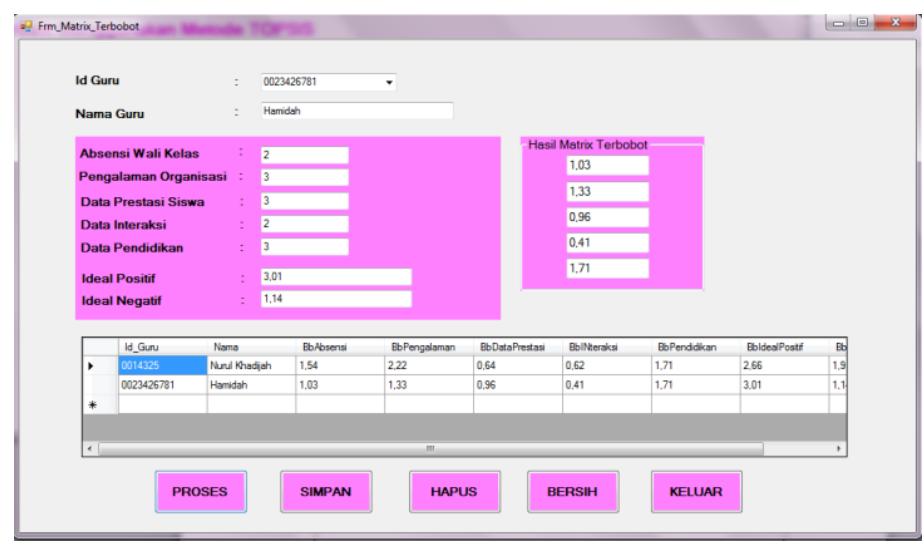

\section{Gambar 3.5 FormProses Matriks Terbobot}

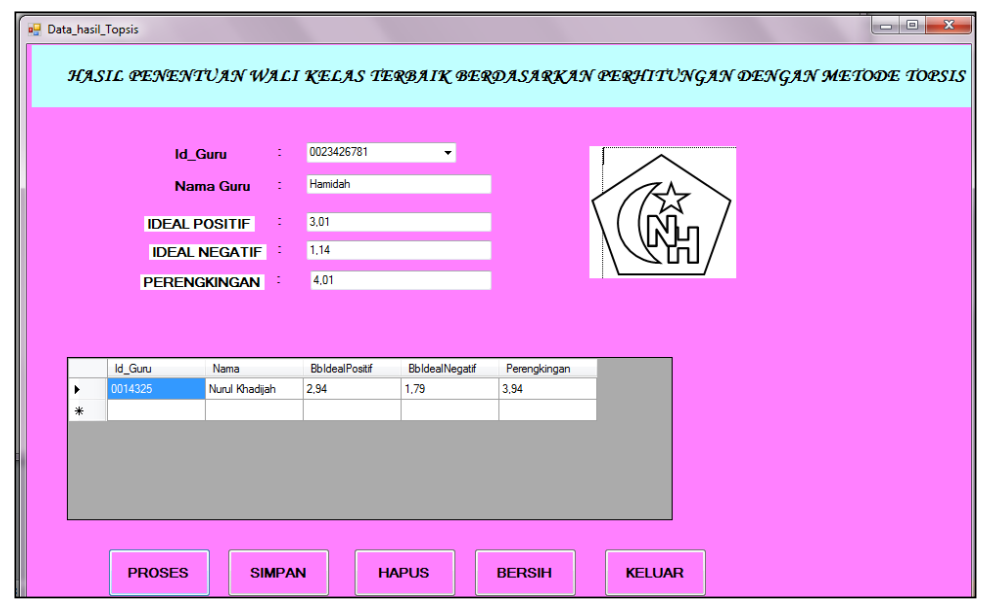

Gambar 3.6 FormProses Pengambilan Keputusan 
decision support system for determining best homeroom teacher with topsis method in MIS nurul huda pantai labu

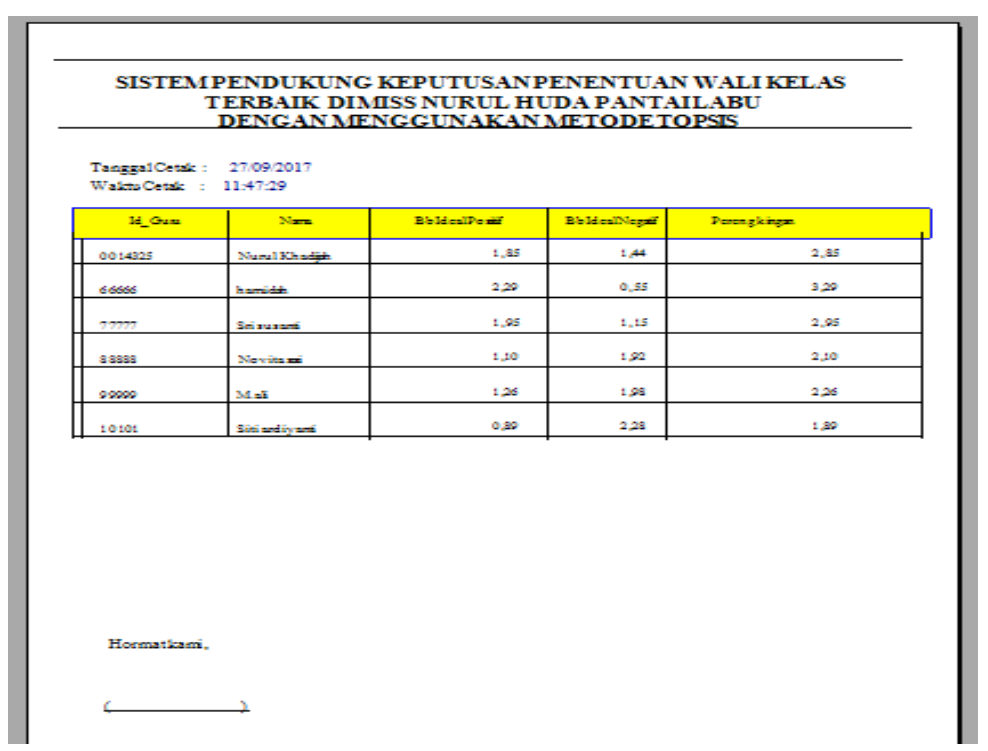

Gambar 3.7 Tampilan Hasil Keputusan Topsis 


\section{KESIMPULAN}

Adapun Kesimpulan dari peneltian ini adalah :

1. Pengguna dapat menentukan penentuan wali kelas terbaik dengan menggunakan sistem yang telah dirancang.

2. Metode Topsis dapat digunakan untuk menentukan penentuan wali kelas terbaik.

3. Membuat aplikasi yang dibangun dengan cara menginput data melalui admin kemudian menghasilkan nilai output setelah melalui proses topsis.

\section{SARAN}

Saran yang dapat disimpulkan dalam penelitian ini yaitu :

1. Adanya pengembangan lebih lanjut dari sistem yang dibangun baik dari tampilan interface dari sistem tersebut agar lebih menarik dan mudah dipahami.

2. Adanya penggabungan metode Topsis dengan metode yang lain sehingga dapat memperluas jangkauan dari sistem yang dibangun.

3. Penambahan Fitur dalam sistem yang dibangun.

\section{DAFTAR PUSTAKA}

[1] Aelani, Khoirida., Falahah, dan Dandy Handoza. 2014. Penerapan Metode TOPSIS pada Aplikasi Pendukung Keputusan Pemilihan Smartphone. Jakarta: SINAPTIKA

[2] E. Mulyasa., 2012,Menjadi Guru Profesional Menciptakan Pembelajaran Kreatif dan Menyenangkan, Rosdakaya, Bandung.

[3] Halim. A, Ricky. 2016. Aplikasi Sistem Pendukung Keputusan Pemilihan Siswa TeladanMenggunakan Metode TOPSIS. IImiah Fifo. Vol VIII. Hal 113.

[4] Hidayat.Slamet, Rita.I, Kasmi. 2016. Sistem Pendukung Keputusan Pemilihan Guru Teladan MA AL MUBAROK RAJA Menggunakan Metode TOPSIS. Technology Acceptance Model.Vol 6. Hal 1-2.

[5] Kurniawan, Helmi, 2015, Sistem Pendukung Keputusan Penilaian Kinerja Karyawan Menggunakan Metode Topsis Berbasis Web pada CV. Surya Network Indonesia, Konfrensi Nasional Sistem dan Informatika, Bali, Oktober 2015.

[6] Kusrini, 2007,Konsep Dasar dan Aplikasi Sistem Pendukung Keputusan, Andi,Yogyakarta.

[7] Maryam, Siti.Siregar. ,2015, Sistem Pendukung Keputusan Pemilihan Guru Teladan di SMA Era Utama Pancur Batu Dengan Menggunakan Metode Topsis, Pelita Informatika Budi Dharma, Vol.IX No. 2. 